\title{
Occurrence of Dipetalonema gracile in a wild population of woolly monkey Lagothrix poeppiigii in the northeastern Peruvian Amazon
}

Ocorrência de Dipetalonema gracile em uma populaçáo selvagem de macaco barrigudo Lagothrix poeppigii no nordeste da Ámazônia peruana

David Fernandez Conga ${ }^{1 *}$; Pedro Mayor $^{2}$; Adriano Penha Furtado ${ }^{1}$; Elane Guerreiro Giese ${ }^{1,3}$; Jeannie Nascimento dos Santos ${ }^{1}$

\author{
${ }^{1}$ Laboratório de Biologia Celular e Helmintologia “Profa. Dra. Reinalda Marisa Lanfredi”, Instituto de Ciências Biológicas, \\ Universidade Federal do Pará - UFPA, Belém, PA, Brasil \\ ${ }^{2}$ Departament de Sanitat i d'Anatomia Animals, Facultat de Veterinària, Universitat Autònoma de Barcelona - UAB, \\ Barcelona, CT, España \\ ${ }^{3}$ Laboratório de Histologia e Embriologia Animal, Instituto de Saúde e Produção Animal na Amazônia, Universidade Federal Rural \\ da Amazônia - UFRA, Belém, PA, Brasil
}

Received October 18, 2017

Accepted February 5, 2018

\begin{abstract}
Dipetalonema gracile (Rudolphi, 1809) (Filarioidea: Onchocercidae) is one of six species of cavities filarial parasites of Neotropical non-human primates. The present study recorded the occurrence of $D$. gracile, provides morphological and morphometric data and extends the geographical distribution. Adult filariae were obtained from the thoracic and abdominal cavities of 38 specimens of woolly monkey, which were used for local human consumption, in the northeastern Peruvian Amazon. Male and female filarids were processed and analysed using light and scanning electron microscopy. Details of the cephalic papillae, post-cloacal bands and papillae, vulva, phasmid position and lateral appendages are showed by scanning electron microscopy and is recorded the occurrencce of Lagothrix poeppigii monkey as a new host of this filaria in the Yavari-Mirin river basin, Peruvian Amazon.
\end{abstract}

Keywords: Dipetalonema gracile, Lagothrix poeppigii, woolly monkey, Peruvian Amazon.

\section{Resumo}

Dipetalonema gracile (Rudolphi, 1809) (Filarioidea: Onchocercidae), é uma das seis espécies de filarias parasitas de primatas não humanos neotropicais. O presente trabalho registra a ocorrência de $D$. gracile, proporciona dados morfológicos e morfométricos e amplia sua distribuição geográfica. Filárias adultas foram obtidas da cavidade torácica e abdominal de 38 espécimes de macaco barrigudo, que foram utilizados para consumo humano local. Essa espécie de primatas não humanos neotropicais tem distribuição ao nordeste da Amazônia peruana. Filarídeos machos e fêmeas foram processados e analisados pela microscopia de luz e microscopia eletrônica de varredura. Detalhes das papilas cefálicas, bandas e papilas pós-cloacais, vulva, posiçáo dos fasmídeos e apêndices laterais são mostradas pela microscopia eletrônica de varredura e registra-se a ocorrência do macaco Lagothrix poeppigii como novo hospedeiro desta filaria na bacia do rio Yavari-Mirin na Amazônia peruana.

Palavras-chave: Dipetalonema gracile, Lagothrix poeppigii, macaco barrigudo, Amazônia peruana.

\footnotetext{
*Corresponding author: David Fernandez Conga. Laboratório de Biologia Celular e Helmintologia "Profa. Dra. Reinalda Marisa Lanfredi", Instituto de Ciências Biológicas, Universidade Federal do Pará - UFPA, Rua Augusto Correa, 1, CEP 66075-110, Guamá, Belém, PA, Brasil. e-mail: daket17@gmail.com
} 


\section{Introduction}

The genus Dipetalonema (DIESING, 1861) belongs to the family Onchocercidae, and it has had other names including Filaria (RUDOLPHI, 1809; MOLIN, 1858) and Acanthocheilonema (BOULENGER, 1920). Rodents, pinnipeds and non-human primates have previously been considered to be hosts (ELEY, 1981; NOTARNICOLA et al., 2007), but phylogenetic studies conducted by Lefoulon et al. (2015) restricted Dipetalonema to non-human primate hosts in the Neotropics.

However, the geographical distribution of Dipetalonema throughout the Neotropics is imprecise because most records are from captive primates or only one host, such as $D$. freitasi in a necropsy of Cebus capucinus at the London Zoo (BAIN et al., 1987), D. robini in Saimiri sciureus in Guyana (PETIT et al., 1985), D. graciliformis in Saguinus midas in French Guiana (BAIN et al., 1986), and D. yatesi in Ateles chamek in the Beni region of Bolivia (NOTARNICOLA et al., 2007). In the case of D. caudispina and $D$. gracile, most records in the last century have been concentrated in Brazil and Guiana (FREITAS, 1943; NOTARNICOLA et al., 2008) and cover a larger number of non-human primate hosts (WEBBER, 1955; NOTARNICOLA et al., 2008).

According to Dunn \& Lambrecht (1963), D. gracile has been reported in the Neotropics in Ecuador, Peru and Brazil as a parasite of S. sciureus, Ateles paniscus and Saguinus nigricollis, but like the other species of the genus, most reports are not geographically explicit. Furthermore, only the $D$. gracile specimens recorded in S. sciureus have complete descriptions of their morphometric data made by Bain et al. (1986) for specimens from French Guiana (49 ED, Collection of the National Museum of Natural History) and by Notarnicola et al. (2008) for specimens from the Ecuadorian Amazon (CHMLP Nro5556 and Nro5557, Collection of the Museo de La Plata).

The present study describes, for the first time, parasitism by $D$. gracile in the silvery woolly monkey, Lagothrix poeppigii (Schinz, 1844), which is one of the largest non-human primates found in the western Amazon and is commonly hunted for food by human subsistence hunters. In addition to extending the list of host species, this study performed an extensive morphological analysis of $D$. gracile with use of scanning electron microscopy.

\section{Materials and Methods}

Between 2009 and 2013, 38 silvery woolly monkeys (18 males and 20 females) were killed for subsistence hunting in the Yavari river basin, which is between the Yavari and Yavari-Mirin rivers

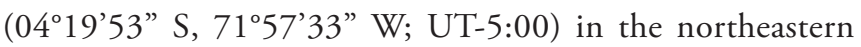
Peruvian Amazon in the Loreto region. According to Bodmer et al. (2003), hunting is a common activity in the area, so local hunters and residents have been incorporated into a natural resource management programme and taught to remove and identify the abdominal and thoracic organs of primate prey, preserve them in a $10 \%$ formaldehyde fixative solution and deliver them to researchers.

The protocol authorizing this study and the sample collection was approved by the Peruvian Forest and Wildlife Service (Servicio Forestal y de Fauna Silvestre; Committee for Ethical
Wildlife Research, protocol no. 0127-2010, 0229-2011 and 0350-2012-DGFFS-DGEFFS). The helminths were retrieved from the external surfaces of the thoracic and abdominal organs of the silvery woolly monkeys, washed in saline solution and preserved in $70 \%$ ethanol. The samples were then shipped to the Laboratory of Cell Biology and Helminthology of the Institute of Biological Sciences at the Federal University of Pará, Brazil, under import permit no. 02309-MINAGRI-SERFOR.

Following Gardner's (1996) protocol, the helminths were dehydrated in ethanol and cleared in 50\% Amann's lactophenol to study their morphological and morphometric characteristics, and cross-sections of the nematodes were placed on slides with coverslips and analysed. Some of the samples were analysed using an Olympus BX41 microscope and an Olympus SZX12 stereomicroscope (Melville, New York, USA), both of which were equipped with a light chamber.

Samples were prepared for scanning electron microscopy following the protocol of Furtado et al. (2010). Male and female helminths were sectioned at $2 \mathrm{~cm}$ from their anterior and posterior ends, and the parts were analysed using a TESCAN Vega 3 LMU scanning electron microscope (Kohoutovice - Czech Republic). The morphometric analysis was based on 20 adult male and 20 adult female specimens. Measurements of the total length of the nematodes and the caudal area rugosa of males were taken in millimetres, and measurements of the other anatomical structures were taken in micrometres. The obtained values are presented below in the following format: mean and standard deviation followed by the range between the lowest and highest values in parentheses.

\section{Results}

\section{Onchocercidae (CHABAUD \& ANDERSON, 1959) \\ Dipetalonema gracile (RUDOLPHI, 1809) \\ Description}

(Figures 1-4, Table 1)

Long pale body with fine transverse striations and thickening on the sides along the length of the body beginning at the nerve ring and ending near the tip of the tail in both sexes (Figure $3 \mathrm{~A}$ and $\mathrm{E}$ ). The ratio of the size of females to males is 1:1.7. The cephalic structure has a smooth quadrangular shape with four cephalic papillae and four labial papillae located around a simple, small mouth composed of four dorsal and four ventral papillae; the amphids are arranged between the cephalic papillae (Figures 1B, 2B, 3A and 4A). The oesophagus is divided into the muscular region (anterior and short) and the glandular region (posterior and long), and the nerve ring is located in the muscular region of the oesophagus. Posteriorly to the nerve ring there is a small, discrete excretory pore (Figures $1 \mathrm{~A}$ and $2 \mathrm{~A}$ ). In both males and females, the posterior extremity ends in a conic tail accompanied by caudal appendages on either side with the phasmid at the base (Figure 3F).

Male (description based on 20 adult specimens). Total body 91 (62-105), small buccal capsule 5 (3-7) × 13 (9-13) (Figures 1B and 3A); nerve ring 196 (179-232), excretory pore 284 (211-347) (Figure 1A), total length of oesophagus 2568 (2227-3120), muscular oesophagus 415 (347-579), width 
of body at the intestine 270 (190-337) (Figure 1D), testicles beginning at the level of the oesophagus/intestine transition (Figures 1C and D). Posterior extremity of male with 6-8 spiral twists and small longitudinal striations in the form of transverse bands with microstriations on the ventral caudal surface forming the area rugosa 12 (7-16) (Figure 3B). Post-cloacal bands arranged in two rows, the right shorter than the left (Figure 3D). Left spicule measured 951 (813-1064) (Figure 1F) and subdivided into the proximal handle 251 (219-301), membranous alae 351 (283-560) and flagellum 349 (173-493); the latter two regions forming the lamina 700 (595-803). Right spicule, simple 192 (160-221) and gubernaculum small 18 (16-19). Handle/lamina ratio $=2.8$, and right spicule/left spicule ratio $=5$; tail 298 (267-320). Seventeen sessile caudal papillae (Figures $1 \mathrm{E}$ and $3 \mathrm{C}, \mathrm{F}$ ) arranged in three pairs plus a single central pre-cloacal papilla, a pair of ad-cloacal papillae and two pairs of post-cloacal papillae. Four papillae at the end of the tail in an irregular formation and the caudal

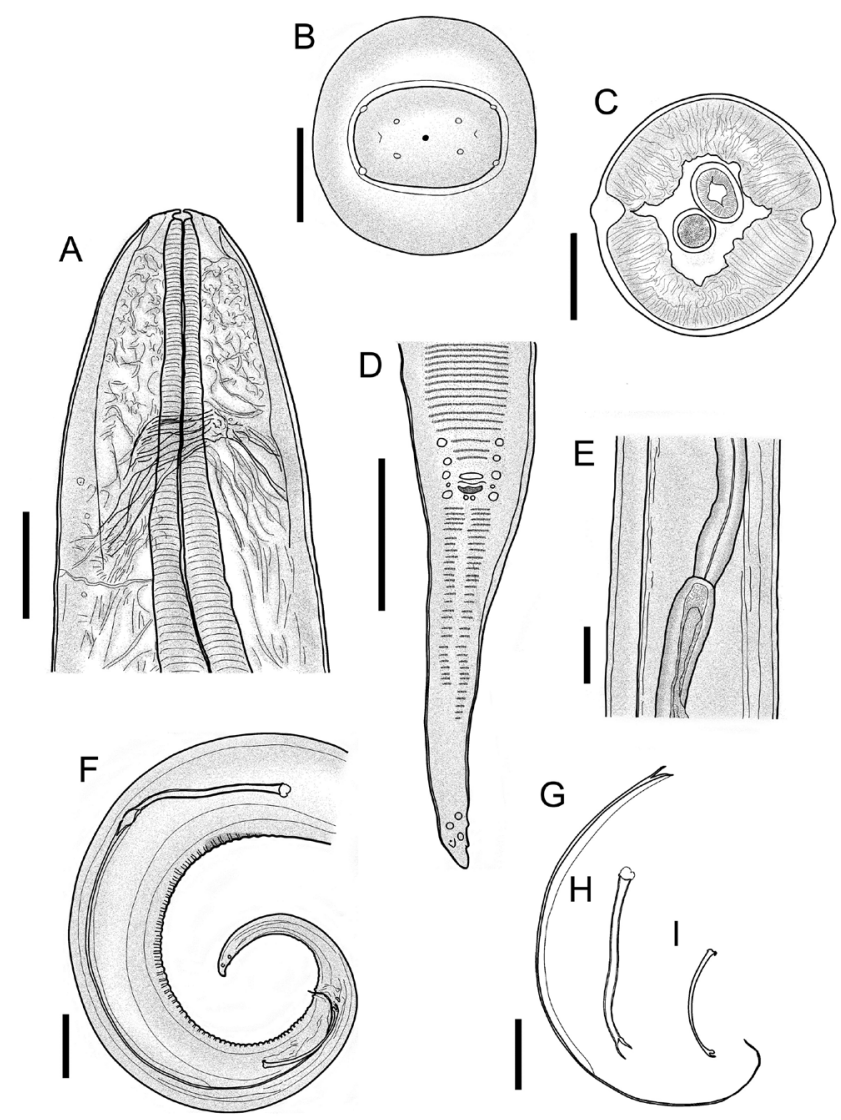

Figure 1. Morphology of D. gracile Male: (A) Cephalic end, lateral view with details of the nerve ring, excretory pore and muscular oesophagus, $\mathrm{Bar}=50 \mu \mathrm{m}$; (B) Cephalic end, apical view. $\mathrm{Bar}=50 \mu \mathrm{m}$; (C) Cross section of the body at the level of the intestine and testis. Bar $=100 \mu \mathrm{m}$; (D) Ventral view of posterior end with details of the caudal papillae of the cloacal band. Bar $=100 \mu \mathrm{m}$; (E) Lateral view with detail of the testes and oesophagus-intestine. Bar $=100 \mu \mathrm{m}$; (F) Posterior end, lateral view with details of the spicules and cloaca. Bar $=10 \mu \mathrm{m}$; $(\mathrm{G})$ Membranous alae. Bar $=10 \mu \mathrm{m} ;(\mathrm{H})$ Flagella. Bar $=10 \mu \mathrm{m}$; (I) Right spicule. Bar $=10 \mu \mathrm{m}$. appendages measuring 3 (3-5) with the distance from the tip of the tail to the phasmids at the base of the lateral caudal appendages measuring 22 (21-27); in addition, fine irregular striations are observed around the caudal papillae and appendages (Figure 3F).

Female (description based on 20 adult specimens). Body length 160 (115-191), width at the level of the oesophagus/intestine 349 (274-416) (Figure 2C), small buccal capsule 6 (4-8) × 13 (10-13) (Figure 2B); nerve ring 199 (147-237), excretory pore 300 (253-384), length of the oesophagus 3069 (2693-3507), muscular oesophagus 467 (369-721) (Figure 2A). Vulva posterior to the muscular oesophagus 776 (547-1021) (Figure 4C). Sinuous vagina vera measuring $242(199-305) \times 63(52-82)$ (Figure 2E). Ovijector 4388 (3733-5760) directed towards the posterior extremity. Uterine microfilariae $109(104-126) \times 4(3-7)$ (Figures 2D and 4B). Tail measuring 419 (338-494) (Figure 4B), and posterior extremity of the tail with caudal appendages 7 (7-11) with the distance between the tip of the tail and the phasmids at the base of the caudal appendages measuring 17 (11-20) and ending in a digitiform projection (Figures $2 \mathrm{~F}$ and $4 \mathrm{D}$ ).
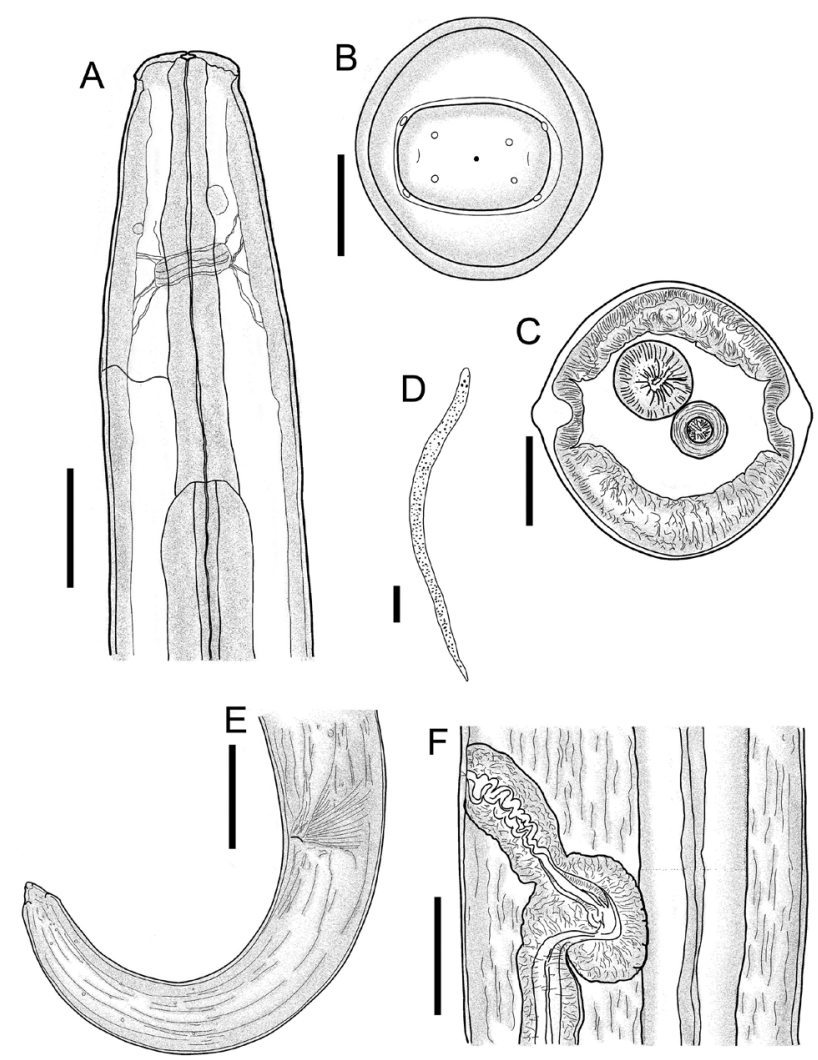

Figure 2. Morphology of D. gracile Female: (A) Cephalic end, lateral view with details of the nerve ring, excretory pore, glandular and muscular oesophagus. Bar $=100 \mu \mathrm{m}$; (B) Cephalic end, apical view. $\mathrm{Bar}=50 \mu \mathrm{m}$; (C) Cross section of the body at the level of the intestine and ovijector. Bar $=100 \mu \mathrm{m}$; (D) Uterine microfilaria Bar $=10 \mu \mathrm{m}$; (E) Posterior end with details of the lappets and anal aperture. $\mathrm{Bar}=100 \mu \mathrm{m}$; (F) Lateral view with details of the vulvar aperture and vagina. Bar $=100 \mu \mathrm{m}$. 

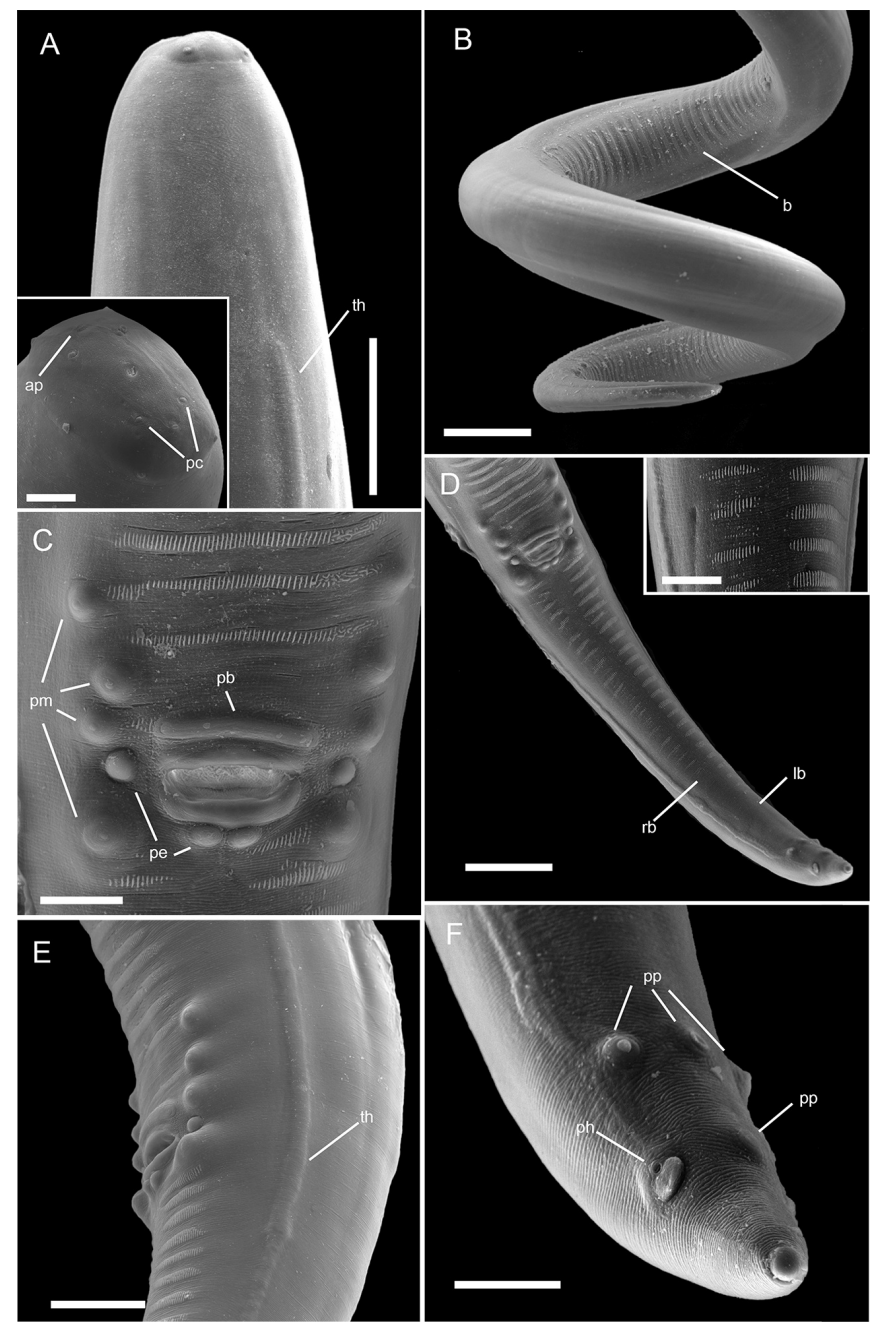

Figure 3. Ultrastructure of D. gracile Male: (A) Cephalic end, lateral and apical view. $B a r=100 \mu \mathrm{m}$. Details of the papillae (pc), amphids (ap) and lateral thickening (th). Bar $=20 \mu \mathrm{m}$; (B) Posterior end, ventral view with details of the bands (b) in the area rugosa. Bar $=100 \mu \mathrm{m}$; (C) Posterior end, ventral view with details of the cloacal papillae ( $\mathrm{pm}$, pe and $\mathrm{pb}$ ). Bar $=10 \mu \mathrm{m}$; (D) Posterior end, ventral view. $\mathrm{Bar}=50 \mu \mathrm{m}$. Details of the post-cloacal bands ( $r b$ and lb). Bar $=10 \mu \mathrm{m}$; (E) Posterior end, lateral view with details of the lateral thickening (th). Bar $=10 \mu \mathrm{m}$; (F) Posterior end, ventral view with details of the lappets, phasmids (ph) and caudal papillae (pp). Bar $=10 \mu \mathrm{m}$.

\section{Taxonomic summary}

Host: Lagothrix poeppigii Schinz (1844) (Primates: Atelidae).

Site of infection: filariae observed among the organs of the abdominal and thoracic cavities.

Locality: Yavari-Mirin and Yavari river basin, Peruvian Amazon (S0 04²7.5'; W0 7145.9').

Prevalence: $100 \%$ (38 examined hosts, 18 males and 20 females).

Mean infection intensity: 30.6 (3-108).

Specimens deposited: three males (No. MPEG 071-073) and three females (No. MPEG 074-076). Voucher specimens deposited in the Invertebrate Collection of the Museu Paraense Emilio Goeldi (MPEG, Belém, Pará, Brazil).

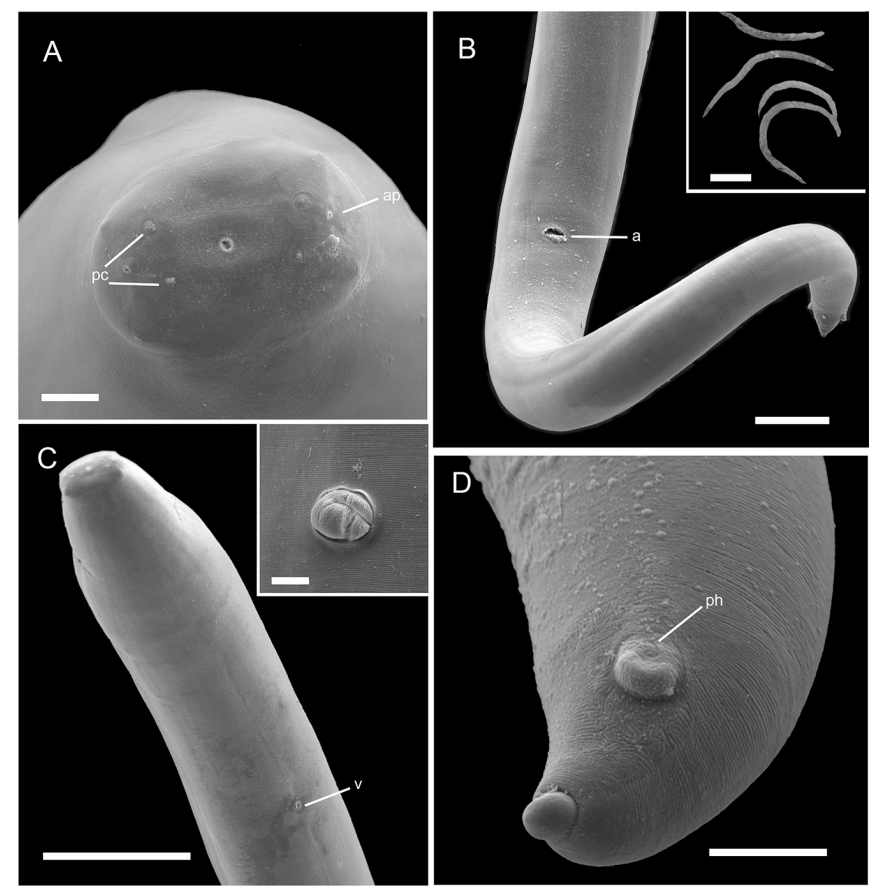

Figure 4. Ultrastructure of D. gracile Female: (A) Cephalic end, apical view with details of the papillae (pc) and amphids (ap). Bar $=20 \mu \mathrm{m}$; (B) Posterior end, ventral view with details of the anal aperture (a). Bar $=50 \mu \mathrm{m}$. Uterine microfilaria. Bar $=20 \mu \mathrm{m}$; (C) Anterior end, lateral view. Bar $=200 \mu \mathrm{m}$. Details of the vulvar aperture (v). Bar $=10 \mu \mathrm{m}$; (D) Posterior end with detail of the lappets and phasmids (ph). Bar $=10 \mu \mathrm{m}$.

\section{Discussion}

Detailed analysis of the structures of male and female specimens found in 38 L. poeppigii hosts revealed their compatibility with D. gracile, initially denominated Filaria gracilis by Rudolphi (1809). Characteristics such as the difference in the size of the spicules and the divided oesophagus placed the specimens within the genus Dipetalonema, which was originated described by Diesing (1861). There are currently six filariae species of the genus Dipetalonema that are exclusive to the peritoneal and thoracic cavities of Neotropical primates: D. caudispina, D. graciliformis, D. yatesi, D. gracile, $D$. freitasi and D. robini. Specific denomination is possible due to differences in the morphology of the reproductive organs of these six species.

Among the female specimens of the six Dipetalonema species, the shape of the vagina is distinctive; $D$. caudispina, D. yates $i$ and $D$. freitasi have a simple, straight vaginal canal that is structurally less complex than those found in the other three species, D. robini, D. graciliformis and D. gracile; the latter two have vaginas with similar sinuous shapes. The vulvar opening of the D. gracile from L. poeppigii has well-developed labias as well as caudal appendages, of which those at the end of the tail have phasmids at the base. These characteristics are shown in detail for the first time by scanning electron microscopy, which also shows the lateral thickening along the body in both sexes of the nematode. The uterine microfilariae 


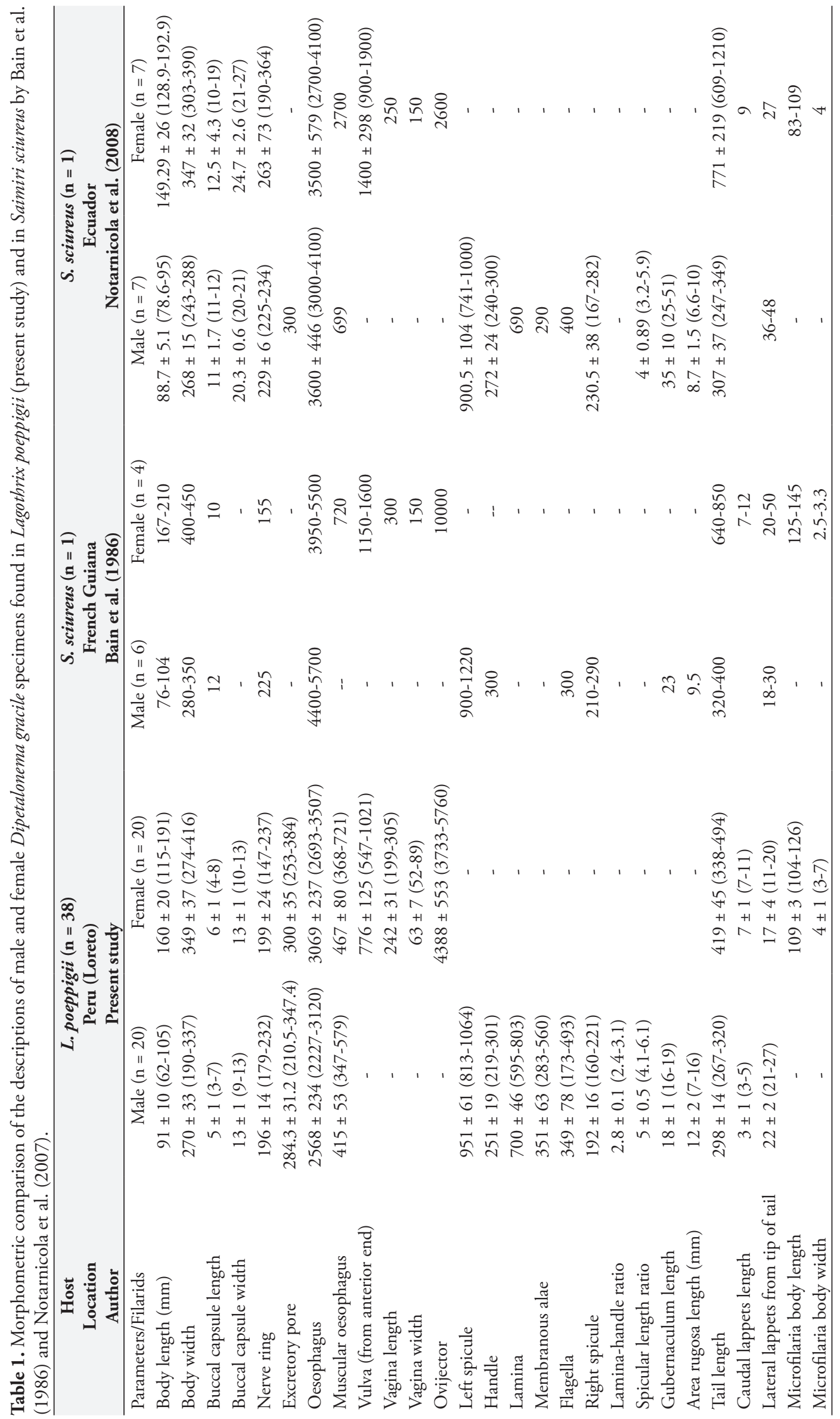


of $D$. gracile from L. poeppigii have morphometric values similar to those found by Notarnicola et al. (2008) and Bain et al. (1986).

The structure of the left spicule of $D$. gracile described from L. poeppigii is similar to that described by Bain et al. (1986), with the division into three structures: the handle, membranous alae and flagellum; the latter two comprise what is termed the lamina, which has a ratio of 2.8 relative to the handle. Additionally, the membranous alae is larger, on average, than that in the only existing data reported by Bain et al. (1986). The right spicule is a simple structure with a mean length ratio of five relative to the left spicule, which was similar to the findings of Yeh (1956) and Notarnicola et al. (2008) and should be considered an important taxonomic trait in the species description.

In the male specimen, the cloacal papillae present marked differences, being 12 of circular format with difference in size and a papilla in format of central bar. These structures are more noticeable in scanning electron microscopy and were not highlighted in the studies of Bain et al. (1986) and Notarnicola et al. (2008). Another important male characteristic are the spiral twists in the area rugosa, which were found to be six to eight in number; these structures were larger in the present study than those found by Bain et al. (1986) and Notarnicola et al. (2008). This trait may vary given the difficulty of measuring that region of the body due to the twists in the tail.

A discrete excretory pore was observed in both sexes of the D. gracile parasite of L. poeppigii in this study, which was not previously reported. However, the location of the excretory pore relative to the anterior extremity coincides with the value described by Notarnicola et al. (2008) in the female. Compared to the data presented by Bain et al. (1986) and Notarnicola et al. (2008), additional morphometric differences were also observed in the present study, including the larger size of the ovijector and smaller sizes of the buccal capsule, oesophagus, gubernaculum, caudal appendages, distance of the vulva and nerve ring from the anterior extremity, and a significantly smaller tail in the female. However, there was no significant difference in the total body size found by those authors and in this study. These variations can be attributed to the inclusion of a much larger number of specimens in this study, which resulted in more complete morphometric data.

Dunn \& Lambrecht (1963) reported finding specimens of D. gracile in some primate hosts in the Peruvian Amazon without providing the correct taxonomic identification. These authors reported $A$. paniscus, $T$. nigricollis ( $S$. nigricollis), $S$. sciureus and S. boliviensis (DUNN \& LAMBRECHT, 1963) as hosts without specifying exact geographical locations. However, it's already known that the distribution of $D$. gracile or other species of filariae may be much wider, given that there are more than 40 species of primates in Peru and large geographical areas that have not yet been studied. Other initial reports for $D$. gracile or synonyms in the Americas (BOULENGER, 1920; WEBBER, 1955) are based on zoo animals or individual cases for which the precise geographic origin of the host, and hence the parasite, is unknown, hampering efforts to assemble an ideal and accurate record. The 38 infected hosts in our study represent a wide geographic distribution of filariasis in non-degraded natural areas and are not limited to representing hosts in captivity.
Due the great diversity of hosts and the difficulty of reaching large geographic areas for research, gaps in our knowledge of natural infections of filariae in Neotropical primates remain. Therefore, in situ studies are needed to gain an accurate view of the distribution of filariae in natural areas. We have presented the occurrence of $D$. gracile as a parasite in the thoracic and peritoneal cavities of $L$. poeppigii under natural infection conditions with additional details about its morphometry and morphology as well as images of its ultrastructure. This is the first record of its presence in this host and in the Amazonian region of northeastern Peru.

\section{Acknowledgements}

The authors thank the people of Nueva Esperanza, all of whom actively participated in the data collection, demonstrating that community participation is an important step in the development of wildlife management strategies. Institutional support was provided by the Servicio Forestal y de Fauna Silvestre (SERFOR) Ministerio de Agricultura of Peru. This work was made possible by the institutional support of the Fundació Autònoma Solidària of the Universidad Autónoma de Barcelona. We thank to the Laboratory of Animal Histology and Embryology (LHEA/Universidade Federal Rural da Amazônia) for providing access to the scanning electron microscope (Vega 3/TESCAN). This study was funded by the CAPES Foundation of the Ministry of Education of Brazil (grant CAPES - Basic Parasitology/2010), grant PAPQ 2016-PROPESP/UFPA and the National Council for Scientific and Technological Development (CNPq) (CNPq Productivity Research Grant to Santos, JN). This work is part the doctoral dissertation of Conga, D.F. of the Post Graduate Program in Biology of Infectious and Parasitic Agents, ICB-UFPA

\section{References}

Bain O, Diagne M, Muller R. Une cinquième filaire du genre Dipetalonema, parasite de singes sud-américains. Ann Parasitol Hum Comp 1987; 62(3): 262-270. PMid:3662331. http://dx.doi.org/10.1051/parasite/1987623262.

Bain O, Petit G, Rosales-Loesener L. Filaires de singes sud-américains. Bull Mus Natl Hist Nat 1986; 8(3): 513-542.

Bodmer RE, Puertas P, Antunez M. Use and sustainability of wildlife hunting in and around the proposed Yavarí Reserved Zone. In: Pitman N, Vriesendorp C, Moskovits D. Perú: Yavarí: rapid biological inventories. Chicago: The Field Museum; 2003. p. 178-185. (vol. 11).

Boulenger CL. Filariid worms from mammals and birds in the society's gardens, 1914-1915. J Zool 1920; 90(4): 491-505.

Chabaud AG, Anderson RC. Nouvel essai de classification des Filaires (Superfamille des Filarioidea) II. 1959. Ann Parasitol Hum Comp 1959; 34(1-2): 64-87. http://dx.doi.org/10.1051/parasite/1959341064.

Diesing KM. Revision der Nematoden. Sitzungsber. Akad Wiss Wien 1861; 42: 599-605.

Dunn FL, Lambrecht FL. On some filarial parasites of South American primates, with a description of Tetrapetalonema tamarinae $n . s p$. from the Peruvian tamarin marmoset, Tamarinus nigricollis (Spix, 1823). J Helminthol 1963; 37(4): 261-286. http://dx.doi.org/10.1017/S0022149X00019866. 
Eley TJ. Dipetalonema spirocauda in Alaskan marine mammals. JWildl Dis 1981; 17(1): 65-67. PMid:7195944. http://dx.doi.org/10.7589/00903558-17.1.65.

Freitas JFT. Estudos sobre nematodeos filarideos Dipetalonema caudispina (Molin 1858). Mem Inst Oswaldo Cruz 1943; 38(3): 361-372. http:// dx.doi.org/10.1590/S0074-02761943000300005.

Furtado AP, Melo FT, Giese EG, Santos JN. Morphological redescription of Dirofilaria immitis. J Parasitol 2010; 96(3): 499-504. PMid:20557193. http://dx.doi.org/10.1645/GE-2178.1.

Gardner SL. Essential techniques for collection of parasites during surveys of mammals. In: Wilson D, Cole R, Nichols JD, Rudran P, Foster M. Measuring and monitoring biological diversity: standard methods for mammals. Washington: Smithsonian Institution Press; 1996. p. 291-298.

Lefoulon E, Bain O, Bourret J, Junker K, Guerrero R, Cañizales I, et al. Shaking the tree: multi-locus sequence typing usurps current onchocercid (filarial nematode) phylogeny. PLoS Negl Trop Dis 2015; 9(11): e0004233. PMid:26588229. http://dx.doi.org/10.1371/journal.pntd.0004233.

Molin R. Versuch einer Monograpfhie der Filarien. Sitzungsb. D Zool Saml D Mus F Naturk In Berl 1858; 1(2): 3-28.
Notarnicola J, Jiménez FA, Gardner SL. A new species of Dipetalonema (Filarioidea: Onchocercidae) from Ateles chamek from the Beni of Bolivia. J Parasitol 2007; 93(3): 661-667. PMid:17626361. http://dx.doi. org/10.1645/GE-962R1.1.

Notarnicola J, Pinto CM, Navone GT. Host occurrence and geographical distribution of Dipetalonema spp. (Nematoda: Onchocercidae) in Neotropical monkeys and the first record of Dipetalonema gracile in Ecuador. Comp Parasitol 2008; 75(1): 61-68. http://dx.doi.org/10.1654/4284.1.

Petit G, Bain O, Roussilhon C. Deux nouvelles filaires chez un singe, Saimiri sciureus, au Guyana. Ann Parasitol Hum Comp 1985; 60(1): 65-81. PMid:3985534. http://dx.doi.org/10.1051/parasite/198560165.

Rudolphi KA. Entozoorum sive vermium intestinalium historia naturalis. Amsterdam: Tabernae Librariae et Artium; 1809.457 p. (vol. 2, part 1).

Webber WA. The filarial parasites of Primates: a review. I. Dirofilaria and Dipetalonema. Ann Trop Med Parasitol 1955; 49(2): 123-141. PMid:13239074. http://dx.doi.org/10.1080/00034983.1955.11685658.

Yeh LS. Morphological differentiation of Dipetalonema caudispina and D. gracile. Trans R Soc Trop Med Hyg 1956; 50(4): 302-303. 